\title{
STABILISASI TANAH GAMBUT MENGGUNAKAN ABU BOILER KELAPA SAWIT DITINJAU DARI NILAI CBR LABORATORIUM
}

\author{
Fenny Bernavida $^{1}$, Sri Wulandari ${ }^{2}$ \\ ${ }^{1}$ Mahasiswa, Fakultas Teknik Sipil dan Perencanaan, Universitas Gunadarma \\ ${ }^{2}$ Dosen, Fakultas Teknik Sipil dan Perencanaan, Universitas Gunadarma \\ Korespondensi: bernavidaf@gmail.com
}

\begin{abstract}
Palm ash is the waste from the palm ash combustion which contains a lot of silicate. In addition, palm ash also contains inorganic cations such as potassium and sodium. Palm ash is pozzolanic material, which is a non-binding material such as cement, but contains active Silica Oxide (SiO2) compounds which when reacted with free lime or calcium hydroxide $(\mathrm{Ca}(\mathrm{OH} 2))$ and water will form materials such as cement, namely calcium Silica Hydrate. In this study we will use palm ash waste which has been stated to have good soil improvement results as a mixture of peat soil improvement in the hope of getting better improvement results from previous studies in terms of California Bearing Ratio values. The boiler ash to be used is a variation of the mixture of $0 \%, 5 \%, 10 \%$ and $15 \%$ to the weight of the soil sample and using 28 days treatment. The California Bearing Ratio value of the original peat soil is $0.247 \%$, the percentage of $5 \%$ increases to $0.433 \%$, at the percentage of $10 \%$ is $0.629 \%$ and at the percentage of $15 \%$ is $0,729 \%$.
\end{abstract}

Keywords: california bearing ratio, palm ash, peat soil, silicate, stabilization

\section{PENDAHULUAN}

Tanah merupakan dasar penting dalam pembangunan konstruksi yang berfungsi sebagai penyalur beban infrastruktur diatasnya. Ketika tanah dibebani maka tanah akan memadat. Menurut Soekardi dan Hidayat (1988) lahan gambut di Indonesia diperkirakan seluas 18,4 juta hektar yang terbagi atas 4,5 juta Ha di pulau Sumatera, 9,3 juta Ha di pulau Kalimantan dan sekitar 4,6 juta di pulau Irian Jaya dan di pulau-pulau lainnya hanya menempati lembah pedalaman dengan luas yang sedikit [1]. Lahan tersebut memiliki potensi untuk pembangunan infrastruktur jika dapat diperbaiki parameter sifat fisik tanah yang buruknya. Oleh karena itu, dibutuhkan stabilisasi tanah untuk memperbaiki sifat fisik tanah gambut sehingga dapat menjadi dasar tanah yang kuat [2].

Untuk meningkatkan kekuatan dan kekakuan tanah gambut maka dilakukan stabilisasi tanah gambut dengan campuran abu boiler kelapa sawit. Abu boiler kelapa sawit merupakan limbah yang banyak mengandung silikat dan sangat berpotensi tinggi yang dapat digunakan sebagai limbah pengganti semen. Kandungan abu boiler kelapa sawit adalah $\mathrm{SiO}_{2}$ $67,4 \%, \mathrm{CaO} 1,5422 \%, \mathrm{MgO} 3,024 \%, \mathrm{Fe}_{2} \mathrm{O}_{3}$ $0,0014 \%$ dan $\mathrm{Al}_{2} \mathrm{O}_{3}$ 10,9985\% (Endriani, 2012) [3].

Abu boiler kelapa sawit merupakan bahan pozzolanic, yaitu mengandung senyawa Silika Oksida $\left(\mathrm{SiO}_{2}\right)$ aktif yang apabila bereaksi dengan kapur bebas atau kalsium hidroksida $\left(\mathrm{Ca}\left(\mathrm{OH}_{2}\right)\right)$ dan air akan membentuk material seperti semen yaitu kalsium Silika Hidrat [4].

Oleh karena itu perlu dilakukan upaya pemanfaatan limbah tersebut. Penelitian ini dilakukan menggunakan limbah abu boiler kelapa sawit yang telah dikemukakan memiliki hasil perbaikan tanah cukup baik sebagai bahan campuran perbaikan tanah gambut dengan harapan mendapatkan hasil perbaikan yang lebih baik dari penelitian sebelumnya. Abu boiler yang akan digunakan adalah variasi campuran $0 \%, 5 \%, 10 \%$ dan $15 \%$ terhadap berat sampel tanah dan menggunakan pemeraman 28 hari. 


\section{TINJAUAN PUSTAKA}

\subsection{Tanah Gambut}

Tanah gambut terbentuk dari timbunan bahan organik, sehingga kandungan karbon pada tanah gambut sangat besar. Karakteristik kimia tanah gambut di Indonesia sangat beragam dan ditentukan oleh kandungan mineral, ketebalan, jenis tanaman penyusun gambut, jenis mineral pada substratum (di dasar gambut), dan tingkat dekomposisi gambut. Polak (1975) mengemukakan bahwa gambut yang ada di Sumatera dan Kalimantan umumnya didominasi oleh bahan kayu-kayuan [1] [5].

Kadar air tanah gambut berkisar 100 $1.300 \%$ dari berat keringnya (Mutalib et al., 1991). Artinya bahwa gambut mampu menyerap air sampai 13 kali bobotnya, sehingga gambut dikatakan bersifat hidrofilik. Kadar air yang tinggi menyebabkan BD menjadi rendah, gambut menjadi lembek dan daya menahan bebannya rendah (Nugroho et al., 1997; Widjaja-Adhi, 1988) [1].

\subsection{Sistem Klasifikasi Tanah USCS (Unified Soil Classification System)}

Sistem ini pertama kali dikembangkan oleh Casagrande (1942) sebagai sebuah metode untuk pekerjaan pembuatan lapangan terbang oleh The Army Corps of Engineers pada Perang Dunia II. Pada saat ini sistem ini telah dipergunakan secara luas oleh para ahli teknik. Sistem ini selain biasa digunakan untuk desain lapangan terbang juga untuk spesifikasi pekerjaan tanah untuk jalan. Pada tahun 1969 sistem ini diadopsi oleh American Society fot Testing and Materials (ASTM) sebagai Metode Klasifikasi Tanah (ASTM D 2487) [6].

\subsubsection{Stabilisasi Tanah}

Menurut Bowles (1984) apabila tanah yang terdapat di lapangan bersifat sangat lepas atau sangat mudah tertekan atau apabila mempunyai indeks konsistensi yang tidak sesuai, permeabilitas yang terlalu tinggi atau sifat lain yang tidak diinginkan sehingga tidak sesuai untuk suatu proyek pembangunan, maka tanah tersebut harus distabilisasikan [7].

Stabilisasi tanah dapat terdiri dari salah satu tindakan :

1. Meningkatkan kerapatan tanah.
2. Menambah material kohesi dan/atau tanahan gesek yang timbul.

3. Menambah bahan untuk menyebabkan perubahan-perubahan kimiawi dan/atau fisis tanah.

4. Menurunkan muka air tanah (drainase tanah).

5. Mengganti tanah yang buruk.

Metode stabilisasi yang banyak digunakan adalah stabilisasi mekanis dan stabilisasi kimiawi. Stabilisasi mekanis yaitu penambahan kekuatan atau daya dukung tanah dengan jalan mengatur gradasi tanah yang dimaksud. Usaha ini biasanya menggunakan sistem pemadatan tanah. Pemadatan merupakan stabilisasi tanah secara mekanis, pemadatan dapat dengan berbagai jenis peralatan mekanis seperti mesin gilas, benda berat dijatuhkan, ledakan, tekanan statis dan sebagainya (Bowles, 1991) [8] [9].

\subsubsection{Abu Boiler Kelapa Sawit}

Abu boiler kelapa sawit merupakan salah satu limbah pengolahan kelapa sawit. Abu boiler kelapa sawit merupakan sisa dari pembakaran boiler kelapa sawit dalam dapur tungku pembakaran dengan suhu $700^{\circ} \mathrm{C}-800^{\circ} \mathrm{C}$. Abu boiler kelapa sawit berasal dari unit pengolahan kelapa sawit yang penanganan limbah tersebut ditangani secara baik [3].

Abu boiler kelapa sawit merupakan limbah yang mengandung banyak silikat. Selain itu, abu boiler kelapa sawit juga mengandung Kation Anorganik seperti Kalium dan Natrium.

Hayward (1995) menyatakan, dalam bahan pozzolan ada 2 senyawa utama yang mempunyai peranan penting dalam pembentukan semen yaitu $\mathrm{SiO}_{2}$ dan $\mathrm{Al}_{2} \mathrm{O}_{3}$ dan melebur menjadikan kedua senyawa tersebut reaktif terhadap kapur bebas $\left(\mathrm{Ca}\left(\mathrm{OH}_{2}\right)\right)$. Abu boiler kelapa sawit merupakan bahan pozzolanic, yaitu material yang mengikat seperti semen, namun mengandung senyawa Silika Oksida $\left(\mathrm{SiO}_{2}\right)$ aktif yang apabila bereaksi dengan kapur bebas atau kalsium hidroksida $\left(\mathrm{Ca}\left(\mathrm{OH}_{2}\right)\right)$ dan air akan membentuk material seperti semen yaitu kalsium Silika Hidrat [3]. 
Tabel 1. Komposisi Hasil Pembakaran Abu Boiler Kelapa Sawit

\begin{tabular}{cccc}
\hline Parameter & Satuan & $\begin{array}{c}\text { Hasil } \\
\text { Uji }\end{array}$ & Metode Uji \\
\hline $\mathrm{K}_{2} \mathrm{O}$ (Kalium) & $\%$ & 7,40 & SNI 02.2803.2000 \\
$\begin{array}{c}\mathrm{MgO} \\
\text { Magnesium) }\end{array}$ & $\%$ & 3,19 & SNI 02.2804.2005 \\
$\begin{array}{c}\mathrm{CaO} \\
(\text { Calsium })\end{array}$ & $\%$ & 5,32 & SNI 02.2804.2005 \\
$\mathrm{SiO}_{2}$ (Silika) & $\%$ & 52,2 & SNI 02.2804.2005 \\
\hline
\end{tabular}

Sumber : Laboratorium Pusat Penelitian Kelapa Sawit (PPKS) Jl. Brigjen katamso

\subsubsection{California Bearing Ratio}

Pengujian CBR adalah pengujian untuk memperoleh perbandingan antara beban yang dibutuhkan untuk mencapai hasil penetrasi tertentu di dalam sampel tanah pada kondisi kadar air dan berat volume tertentu terhadap beban standar yang dibutuhkan untuk mencapai penetrasi standar (Bowles, 1989) [10].

Cara CBR dikembangkan oleh California State Highway Departement sebagai cara untuk menilai kekuatan tanah dasar jalan (subgrade). CBR menunjukkan nilai relatif kekuatan tanah, semakin tinggi kepadatan tanah maka nilai CBR akan semakin tinggi. Walaupun demikian, tidak berarti bahwa sebaiknya tanah dasar dipadatkan dengan kadar air rendah supaya mendapat nilai CBR yang tinggi, karena kadar air kemungkinan tidak akan konstan pada kondisi ini [10].

Pemeriksaan CBR bertujuan untuk menentukan harga CBR tanah dipadatkan di laboratorium pada kadar air tertentu. Disamping itu, pemeriksaan ini juga dimaksudkan untuk menentukan hubungan antara kadar air dan kepadatan tanah. Pemeriksaan CBR laboratorium mengacu pada AASHTO T-193-74 dan ASTM 1883-73 [11].

Kekuatan tanah dasar tentu banyak bergantung pada kadar airnya. Makin tinggi kadar airnya makin kecil kekuatan nilai CBR dari tanah tersebut. Walaupun demikian, tidak berarti bahwa sebaiknya tanah dasar dipadatkan dengan kadar air rendah supaya mendapat nilai CBR yang tinggi, karena kadar air kemungkinan tidak akan konstan pada kondisi ini. Setelah pembuatan jalan maka air akan meresap ke dalam tanah dasar, sehingga kekuatan dan CBR turun sampai kadar air mencapai nilai konstan. Kadar air konstan inilah yang disebut kadar air keseimbangan [12]. Batas-batas kadar air dan berat isi kering dapat ditentukan dari hasil percobaan laboratorium yaitu percobaan pemadatan dan CBR.

\subsubsection{Hipotesis}

Kombinasi antara tanah gambut dan abu boiler kelapa sawit semakin tinggi dapat menghasilkan peningkatan sifat fisik tanah dan nilai CBR.

\section{METODOLOGI PENELITIAN 3.1 Persiapan Sampel}

Tanah gambut diambil di lokasi Provinsi Jambi dan dibawa ke laboratorium. Setelah itu dilakukan uji indeks properties tanah asli dan pembuatan sampel variasi tanah gambut dan limbah abu boiler kelapa sawit dengan kadar masing-masing $0 \%, 5 \%, 10 \%$ dan $15 \%$ dengan masa pemeraman setiap sampel adalah 28 hari. Masa pemeraman diambil selama 28 hari berdasarkan studi literatur yang sudah ada dan beberapa penelitian yang menunjukkan bahwa 28 hari adalah masa pemeraman paling optimum. Selanjutnya, setiap sampel akan diuji nilai CBR nya. Dari hasil penelitian laboratorium tersebut, akan dianalisis hasil dan dibandingkan dengan sampel tanah asli. Setelah dianalisis, maka dapat disimpulkan variasi yang memberikan hasil paling optimal untuk perbaikan tanah gambut.

\subsection{Tahapan Pengujian}

Uji yang dilakukan setelah sampel tanah asli siap adalah uji indeks properties tanah. Tanah gambut akan dilakukan uji kadar air tanah, kadar bahan organik, uji berat jenis tanah, uji berat isi tanah dan uji analisis gradasi butiran tanah [13]. Setelah itu, pada variasi campuran $5 \%, 10 \%$ dan $15 \%$ yang diperam selama 28 hari akan dilakukan uji indeks properties yang sama kecuali uji analisis gradasi butiran.

Selanjutnya melakukan uji pemadatan tanah dan uji CBR Laboratorium. Uji pemadatan dilakukan untuk mendapatkan nilai kadar air optimum pada tanah gambut yang masing-masing variasi disiapkan 5 sampel dengan jenis kadar air yang berbeda. Setelah didapatkan nilai kadar air optimum, maka dilakukan uji CBR Laboratorium. 

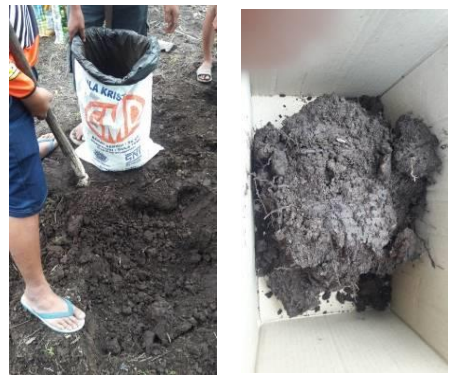

Gambar 1. Proses Pengambilan Sampel Tanah Gambut

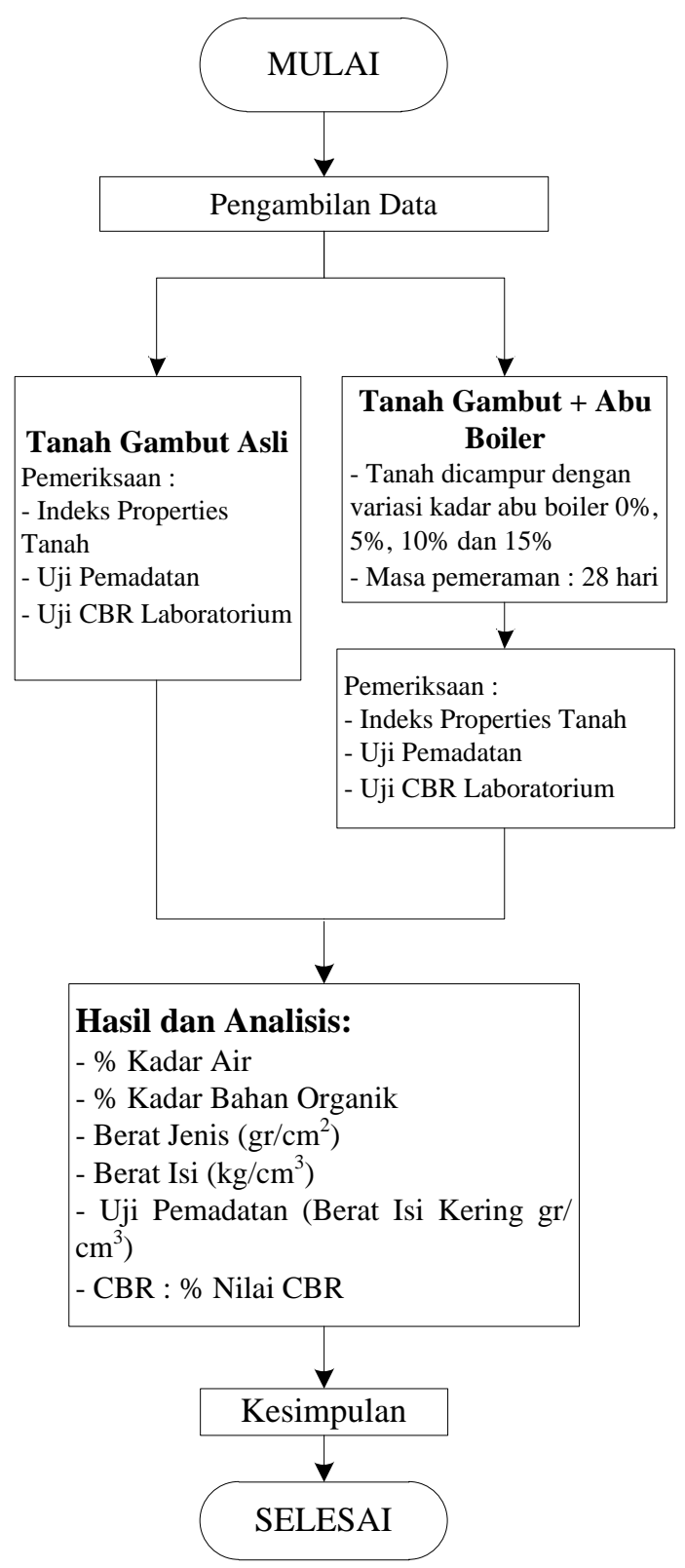

Gambar 2. Flowchart Metodologi Penelitian

\section{HASIL DAN PEMBAHASAN}

4.1 Uji Indeks Properties

4.1.1 Tanah Gambut Asli

Sampel tanah gambut yang diperoleh dari Muaro Jambi masih berupa tanah gambut asli, yaitu tanah gambut yang kondisinya kurang lebih sama seperti kondisi di lokasi asal. Tanah ini kemudian diuji indeks properties dan engineering properties.

Tabel 2. Hasil Uji Indeks Properties

\begin{tabular}{lc}
\hline \multicolumn{1}{c}{ Parameter Pengujian } & Hasil \\
\hline Kadar Air & $276,71 \%$ \\
C-organik & $53,7 \%$ \\
Kadar Bahan Organik & $92,72 \%$ \\
Berat Jenis & 1,425 \\
Berat Isi & $417,470 \mathrm{Kg} / \mathrm{m}^{3}$ \\
AGB & Pasir Kasar \\
\hline
\end{tabular}

Sumber : Penulis

Berdasarkan hasil uji diatas bahwa tanah gambut yang diuji memiliki kadar air <300\% sehingga diklarifikasikan sebagai slightly absorbent (ASTM D2980) dan memiliki kadar bahan organik sebesar $92,72 \%$ dan dapat dikategorikan tanah gambut fibrik (mentah).

\subsubsection{Tanah Gambut dan Abu Boiler Kelapa Sawit}

Tanah gambut asli dicampurkan dengan abu boiler kelapa sawit untuk dilihat pengaruhnya terhadap nilai CBR tanah gambut. Terdapat 3 variasi campuran tanah yaitu variasi pertama adalah tanah gambut asli $+5 \%$ abu boiler kelapa sawit, variasi kedua adalah tanah gambut asli $+10 \%$ abu boiler kelapa sawit, dan variasi ketiga adalah tanah gambut asli $+15 \%$ abu boiler kelapa sawit sehingga ketiga variasi tersebut dilakukan pengujian indeks properties dan engineering properties. 


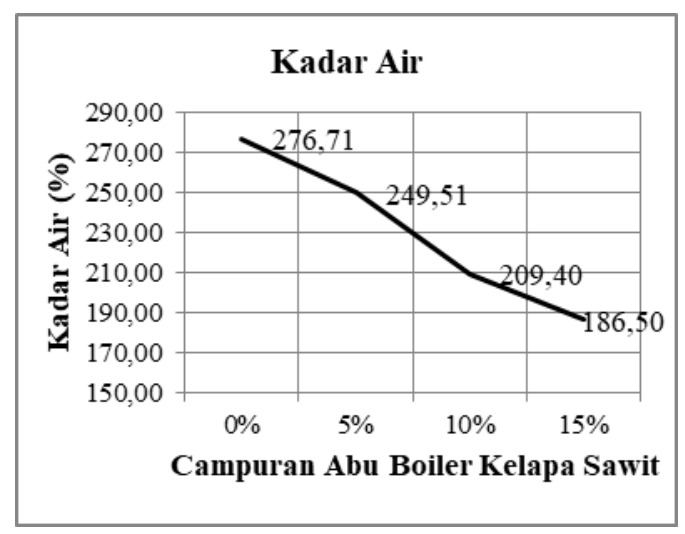

Gambar 3. Kadar Air Tanah Gambut Asli (0\%), Variasi 5\%, Variasi $10 \%$ dan Variasi $15 \%$

Kadar Air awal pada tanah asli adalah sebesar 276,71\% dan terjadi penurunan signifikan menjadi 209,40\% pada kadar abu boiler kelapa sawit 10\%. Pada kadar abu boiler kelapa sawit $15 \%$ kadar air kembali mengalami penurunan namun tidak signifikan menjadi $186,50 \%$.

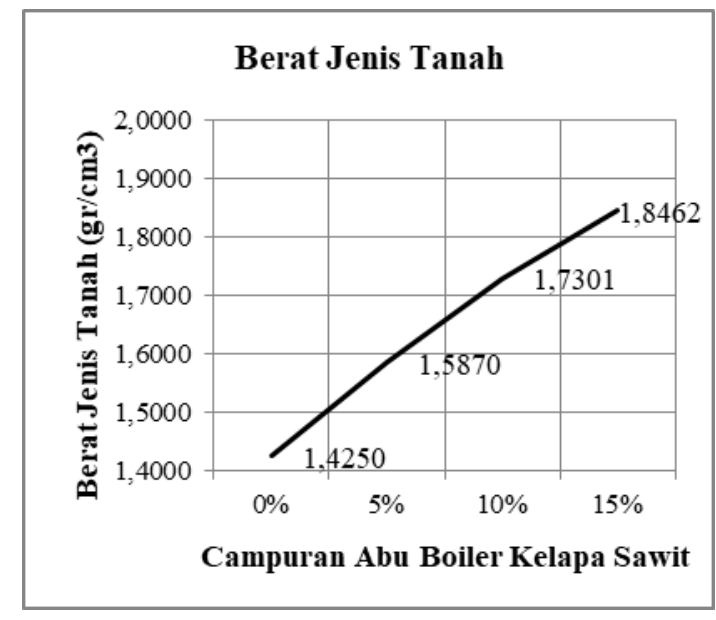

Gambar 4. Berat Jenis Tanah Gambut Asli (0\%), Variasi 5\%, Variasi $10 \%$ dan Variasi 15\%

Meningkatnya berat jenis dikarenakan sifat abu boiler kelapa sawit yang memiliki berat jenis 2,270 (Edison, 2003) yang dimana lebih tinggi dari tanah gambut, sehingga pemcampurannya akan meningkatkan berat jenis campuran. Meningkatnya nilai berat jenis ini akan berpengaruh pada nilai berat isi kering dari tanah. Secara teori, semakin kecil berat jenis tanah, maka semakin kecil pula berat isi keringnya. Begitu pula sebaliknya [14].

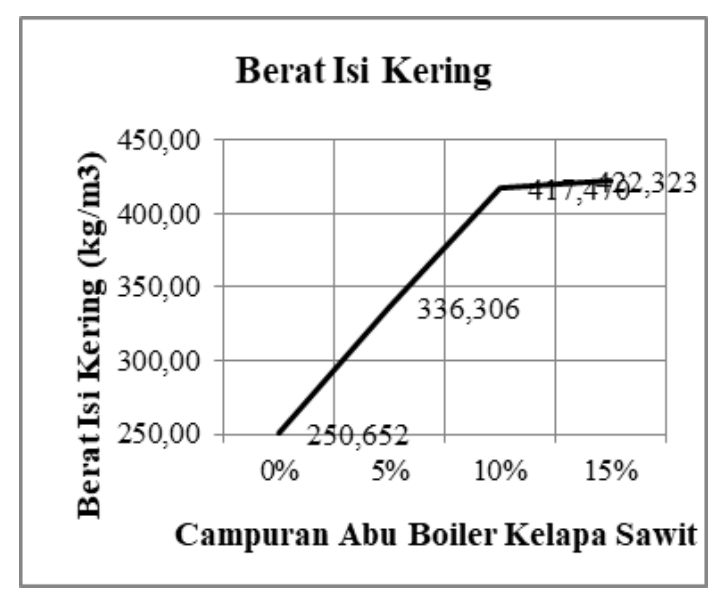

Gambar 5. Berat Isi Kering Tanah Gambut Asli $(0 \%)$, Variasi 5\%, Variasi $10 \%$ dan Variasi $15 \%$

\subsubsection{Uji Pemadatan Tanah}

Hasil pengujian pemadatan tanah pada 4 jenis sampel benda uji dapat dilihat dalam grafik pada gambar berikut :

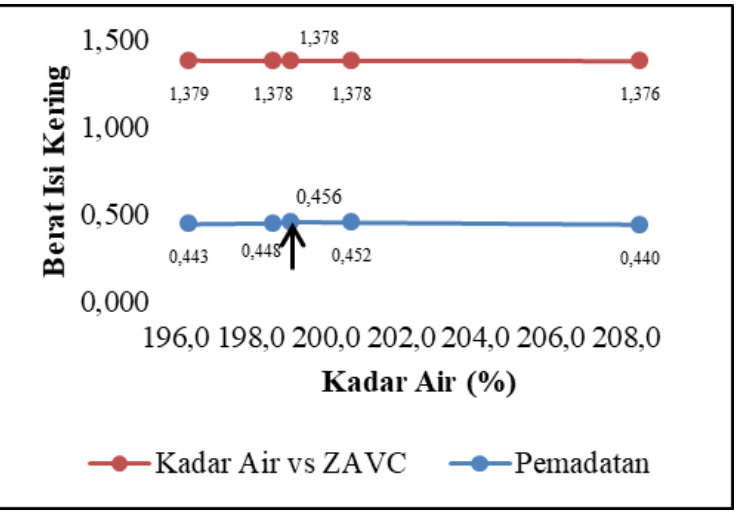

Gambar 6. Hubungan Kadar Air dan Berat Isi Kering Tanah Asli

Pada sampel tanah asli diperoleh berat isi kering maksimum ( $\gamma \mathrm{d}$ maks) $0,456 \mathrm{gr} / \mathrm{cm} 3$ dan kadar air optimum (wopt) 199,061\%. 


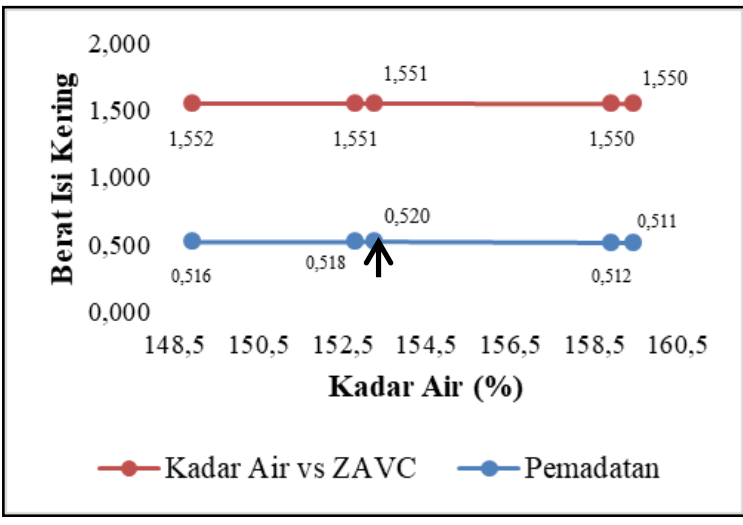

Gambar 7. Hubungan Kadar Air dan Berat Isi Kering Variasi 5\%

Pada sampel tanah variasi 5\% diperoleh berat isi kering maksimum ( $\gamma \mathrm{d}$ maks) 0,520 $\mathrm{gr} / \mathrm{cm} 3$ dan kadar air optimum (wopt) 153,266 $\%$. Nilai berat isi kering maksimum pada variasi ini mengalami peningkatan sebesar $14,03 \%$ terhadap tanah gambut asli.

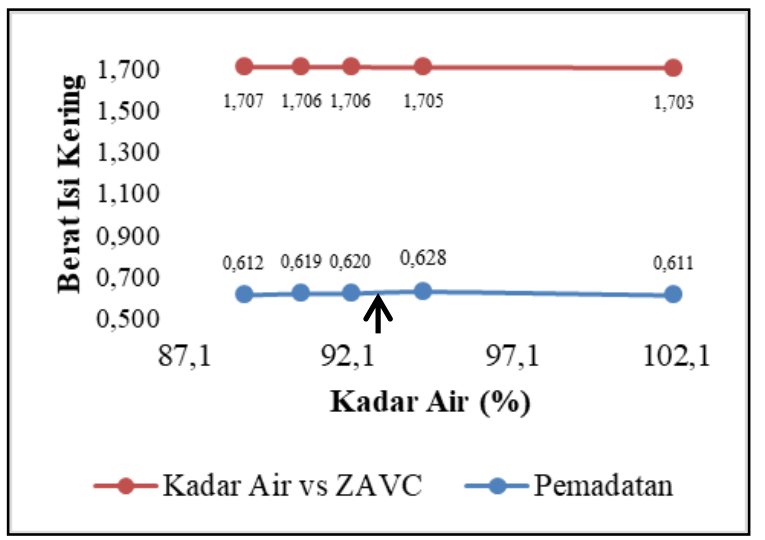

Gambar 8. Hubungan Kadar Air dan Berat Isi Kering Variasi $10 \%$

Pada sampel tanah variasi $10 \%$ diperoleh berat isi kering maksimum ( $\gamma \mathrm{d}$ maks) 0,628 gr/cm3 dan kadar air optimum (wopt) 94,397 $\%$. Nilai berat isi kering maksimum pada variasi ini mengalami peningkatan sebesar $37,71 \%$ terhadap tanah gambut asli.

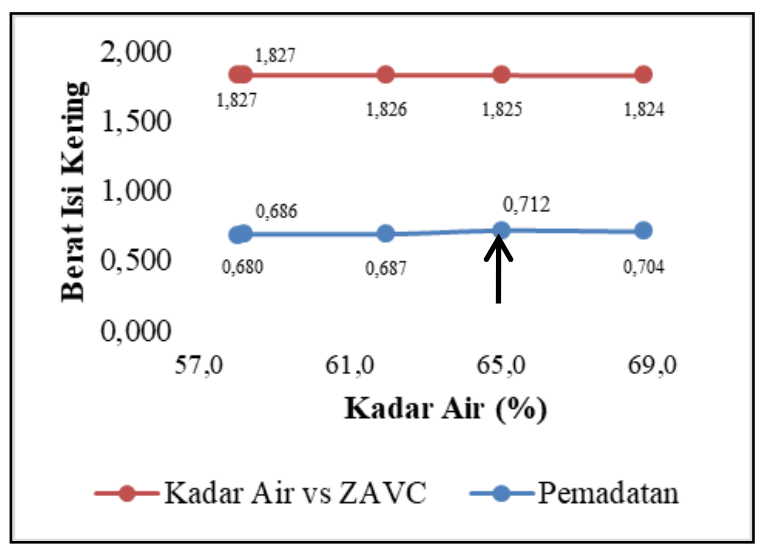

Gambar 9. Hubungan Kadar Air dan Berat Isi Kering Variasi $15 \%$

Pada sampel tanah asli diperoleh berat isi kering maksimum ( $\gamma \mathrm{d}$ maks) $0,712 \mathrm{gr} / \mathrm{cm} 3 \mathrm{dan}$ kadar air optimum (wopt) 65,010\%.

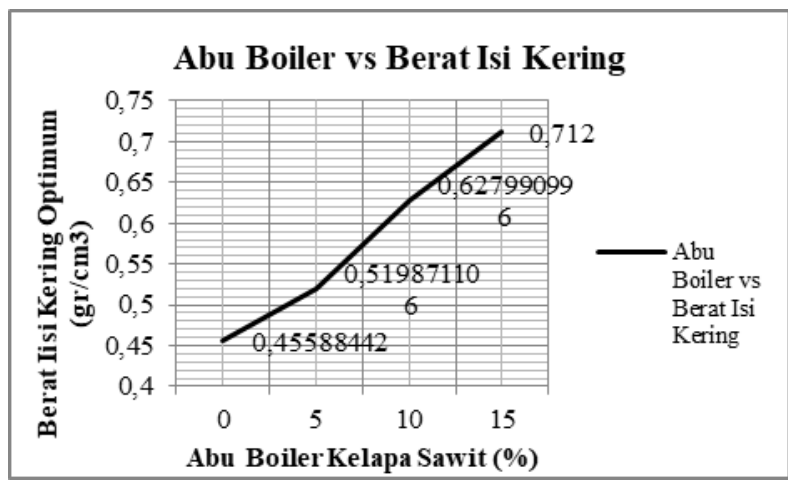

Gambar 10. Pengaruh Penambahan Abu Boiler Kelapa Sawit Terhadap Berat Isi Kering Tanah Asli

Dari hasil tersebut didapat nilai Berat Isi Kering Maksimum Tanah paling maksimum diantara 3 variasi yaitu variasi ketiga dengan kadar abu $15 \%$.

\subsubsection{California Bearing Ratio (CBR)}

Hasil pengujian pemadatan tanah pada 4 jenis sampel benda uji dapat dilihat pada gambar berikut :

Presentase nilai CBR Laboratoriumnya untuk tanah asli, didapatkan nilai CBR sebesar $0,247 \%$. 


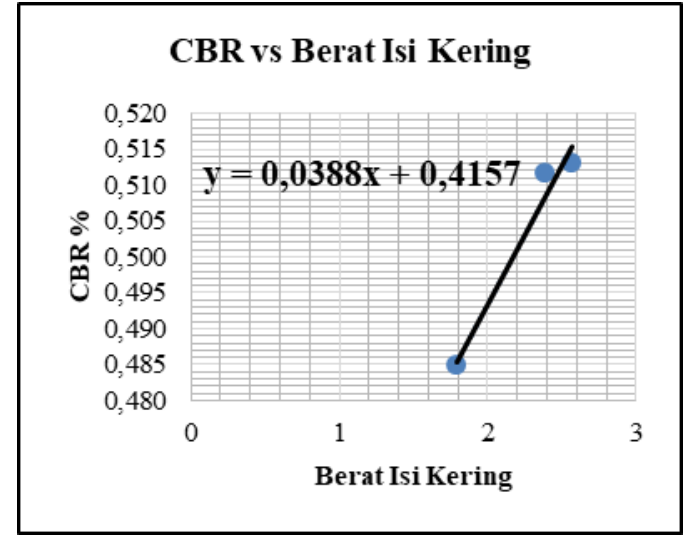

Gambar 11. Hubungan CBR dan Berat Isi Kering Variasi 5\%

Pada gambar terdapat persamaan yang akan digunakan untuk menghitung besar presentase nilai CBR Laboratoriumnya. Maka untuk tanah variasi $5 \%$, didapatkan nilai CBR sebesar $0,433 \%$. Nilai CBR pada variasi ini meningkat sebesar $75,30 \%$ terhadap nilai CBR tanah gambut asli.

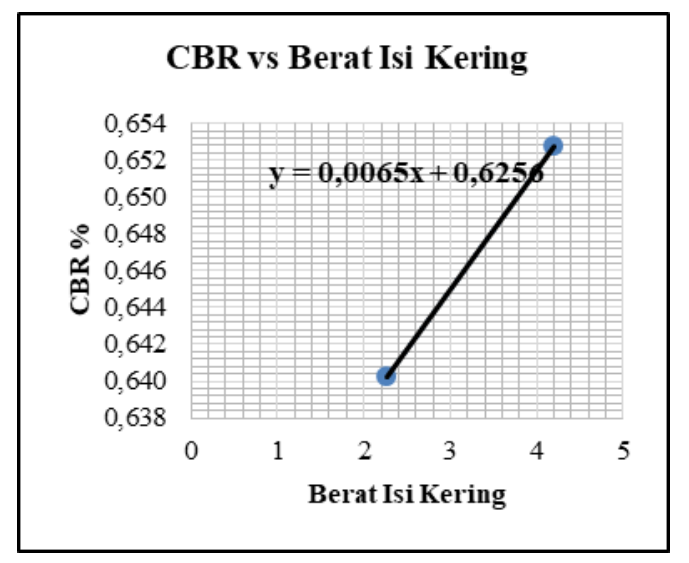

Gambar 12. Hubungan CBR dan Berat Isi Kering Variasi 10\%

Pada gambar terdapat persamaan yang akan digunakan untuk menghitung besar presentase nilai CBR Laboratoriumnya. Maka untuk tanah variasi $10 \%$, didapatkan nilai CBR sebesar 0,629\%. Nilai CBR pada variasi ini meningkat sebesar $154,65 \%$ terhadap nilai CBR tanah gambut asli.

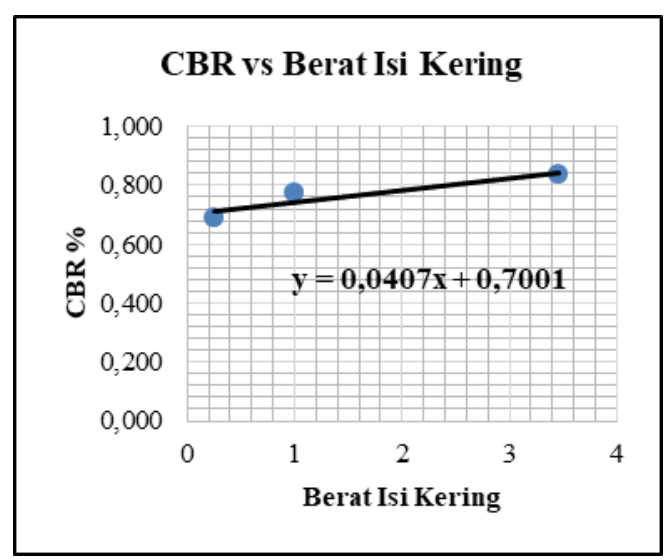

Gambar 13. Hubungan CBR dan Berat Isi Kering Variasi $15 \%$

Pada gambar terdapat persamaan yang akan digunakan untuk menghitung besar presentase nilai CBR Laboratoriumnya. Maka untuk tanah variasi $15 \%$, didapatkan nilai CBR sebesar 0,729 \%. Nilai CBR pada variasi ini meningkat sebesar $295,14 \%$ terhadap nilai CBR tanah gambut asli.

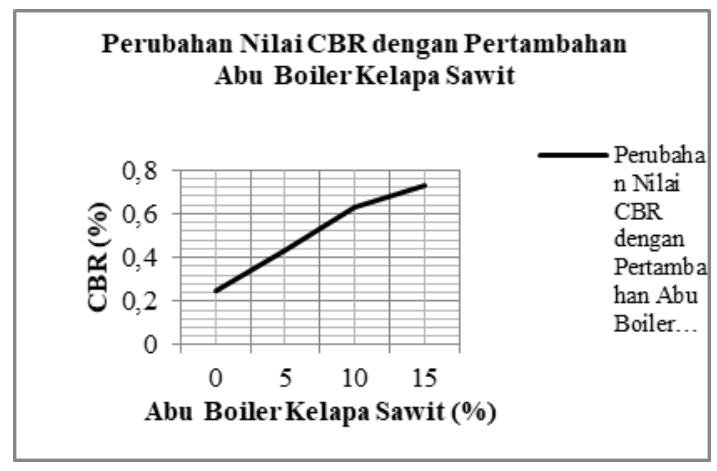

Gambar 14. Pengaruh Penambahan Abu Boiler Kelapa Sawit Terhadap Nilai CBR Tanah Asli

CBR Tanah tanah asli adalah 0,24758\% dan terjadi peningkatan menjadi $0,43338 \%$ pada kadar abu $5 \%$, pada kadar abu $10 \%$ terjadi peningkatan lagi menjadi $0,6296819 \%$, dan kemudian pada kadar abu $15 \%$ terjadi peningkatan menjadi $0,7290873 \%$. 


\section{KESIMPULAN DAN SARAN \\ 5.1 Kesimpulan}

Penelitian ini telah menganalisis peningkatan kekuatan tanah dengan penambahan abu boiler kelapa sawit. Berikut ini adalah kesimpulan yang didapatkan dari proses penelitian ini :

1. Penambahan limbah abu boiler kelapa sawit pada tanah gambut memberikan penurunan kadar air yang signifikan. Kadar air terendah terjadi pada variasi $15 \%$ yaitu sebesar $276,71 \%$ menjadi $186,50 \%$.

2. Peningkatan nilai berat jenis tanah terjadi paling tinggi pada variasi $15 \%$ yaitu sebesar 1,8462. Abu boiler kelapa sawit berhasil meningkatkan nilai berat jenis tanah.

3. Kadar bahan organik yang didapatkan sebesar $92,72 \%$ sehingga tanah tersebut dapat diklasifikasikan sebagai tanah gambut fibrik (mentah).

4. Abu boiler kelapa sawit meningkatkan nilai berat isi kering pemadatan tanah gambut. Nilai berat isi kering paling tinggi sebesar $0,712 \mathrm{gr} / \mathrm{m} 3$ pada variasi $15 \%$.

5. Abu boiler kelapa sawit juga meningkatkan nilai CBR tanah asli sebesar $0,24758 \%$ menjadi $0,72908 \%$ pada variasi $15 \%$. Namun peningkatan yang terjadi tidak signifikan dan masih jauh dikategorikan baik.

\subsection{Saran}

Berdasarkan penelitian yang sudah dilakukan maka penulis menyarankan :

1. Perlu dilakukan penelitian lebih lanjut mengenai campuran efektif untuk tanah gambut ini yaitu penambahan abu boiler kelapa sawit.

2. Perlu diperhatikan cara pencampuran yang efektif abu boiler kelapa sawit pada tanah gambut.

3. Perlu dilakukan penelitian kembali dengan kadar campuran abu boiler kelapa sawit lebih dari $15 \%$.

\section{DAFTAR PUSTAKA}

[1] Balai Besar Litbang Sumber Daya Lahan Pertanian. 2008. Lahan Gambut : Potensi untuk Pertanian dan Aspek Lingkungan. Balai Penelitian Tanah . Badan Pertanian dan Pengembangan Pertanian : Bogor.
[2] Afriwan Toni, Muhardi dan Gunawan Wibisono. 2017. Stabilitas Tanah Gambut dengan Kapur dan Abu Terbang untuk Mengurangi Kebakaran Lahan. Jom FTeknik. Volume: 4 No 1. Universitas Riau: Pekan Baru.

[3] Prianti Epi, Malino, dkk. 2015. Pemanfaatan Abu Kerak Boiler Hasil Pembakaran Limbah Kelapa Sawit Sebagai Pengganti Pasir pada Pembuatan Beton. POSITRON Volume V No 1: Tanjungpura.

[4] Ahmad Refi dan Elvanisa. 2016. Pengaruh Variasi Abu Cangkang Sawit Terhadap Kembang Susut Tanah Lempung. Volume 3, No. 2 ISSN: 2354-8452. Institut Teknologi Padang: Padang.

[5] George R, Otoko, Fubara Isoteim dan Manuel, Ibekwe. 2016. Soft Soil Stabilization Using Palm Oil Fibre Ash.Journal of Multidisciplinary Engineering Science and Technology. ISSN: 2458-9403 Volume 3 Issue 5: Nigeria.

[6] Rama Indera Kusuma, Enden Mina, dkk. 2015. Stabilisasi Tanah Lempung Dengan Menggunakan Abu Sawit Terhadap Nilai Kuat Tekan Bebas (Studi Kasus Jalan Desa Cibeulah, Pandeglang). Jurnal Fondasi Volume 4 No.2. Universitas Sultan Ageng Tirtayasa: Banten.

[7] Endriani, Debby. 2012.Pengaruh Penambahan Abu Cangkang Sawit Terhadap Daya Dukung dan Kuat Tekan Pada Tanah Lempung Ditinjau dari Uji UCT dan CBR Laboratorium. Universitas Sumatera Utara: Medan

[8] Emeka Segun, Olumide M, dan Opeyemi E. 2017. Effects Of Palm Kernel Shell Ash On Lime-Stabilized Lateritic Soil. Slovak Journal of Civil Engineering. Volume 25, No. 3, 1-7: Nigeria

[9] Sim H Plew dan Shakrl M Shariff. 2016. Effects of POFA and Lime On Soft Soil Stabilization. Science International Lahore; ISSN 1013-5316. Universitas SEGi: Malaysia.

[10] Endriani, Debby. 2012.Pengaruh Penambahan Abu Cangkang Sawit Terhadap Daya Dukung dan Kuat Tekan Pada Tanah Lempung Ditinjau dari Uji UCT dan CBR Laboratorium. Universitas Sumatera Utara: Medan

[11] Lubis, Kamaluddin. 2013. Stabilitas Tanah Lempung Dengan Menggunakan Campuran Abu Cangkang Kelapa Sawit Ditinjau dari Nilai CBR. Universitas Medan Area: Medan.

[12] Luhur, Beni, Ariyanto Anton dan Rismalinda. 2016. Stabilisasi Tanah Gambut dengan Campuran Portland Cement Ditinjau 
dari Nilai California Bearing Ratio (CBR). Jurnal UPP.

[13] Ahmad Refi dan Elvanisa. 2016. Pengaruh Variasi Abu Cangkang Sawit Terhadap Kembang Susut Tanah Lempung. Volume 3, No. 2 ISSN: 2354-8452. Institut Teknologi Padang: Padang
[14] Sarifah Jupriah dan Pasaribu Bangun. 2017. Pengaruh Penggunakaan Abu Cangkang Kelapa Sawit Guna Meningkatkan Stabilitas Tanah Lempung. Buletin Utama Teknik. ISSN: 1440-4520. Universitas Islam Sumatera Utara: Medan. 